\title{
Auntie Merkel
}

The course of true love.

\section{Deborah Walker}

An English church. An August wedding.

Auntie Merkel sits at the front of the church, staring at the happy couple. She's wearing her wedding suit, a three-buttoned crocheted jacket over a matching dress. The light from the stained-glass windows reflects off her wing-tipped, milk-bottle glasses.

Two widows, Edith and her sister, Moira, sit whispering to each other, passing comment on the rest of the congregation. They have chosen a respectable position in the middle of the rows of pews: close enough to show that they are family, far enough to show that they are not pushing themselves forward.

"Is that Auntie Merkel?" says Moira. "My word, yes, it is."

"She must be getting on a bit," says Edith. "I remember her being around when I was just a kiddie."

"She attends every family wedding," say Moira. "She must love weddings.”

"She can't love them that much; she's an old maid," says Edith.

"What's that in her bag? It looks like a rat." Moira leans forward to observe the strange creature peeping out from Auntie Merkel's handbag.

“That's Mr Tegmark," says Edith. "Auntie Merkel's hairless cat. She always was rather eccentric."

"It's an odd looking creature," says Moira. When she catches the cat's eye, it disappears into the depths of Auntie Merkel's bag. "That's a cat that doesn't like to be looked at," says Moira with a sniff.

The bride's matron of honour walks to the front of the church. She grips the sides of the eagle lectern. Her voice trembles as she speaks.

"Nerves," says Edith.

The words of the matron of honour flow over the sisters: "Wither thou goest, I will go; and where thou lodgest, I will lodge. Thy people shall be my people, and thy God my God. Where thou diest, will I die, and there will I be buried. The Lord do so to me, and more also, if ought but death part thee and me."

"Ruth is such a lovely book," murmurs Moira.

Edith nods, lost in the past. They had read from the Book of Ruth at her own wedding. Such a happy marriage. She misses her Bert so much ... She seems to remember the glint of reflected light at her ceremony. "She never comes to the reception," she says.

"Who doesn't?"

"Auntie Merkel."

"Ah."

"She never gave me a present, either," whispers Edith, running her finger along the neckline of her dress, which has been bought especially for this wedding and is a little too tight.

\section{(1)}

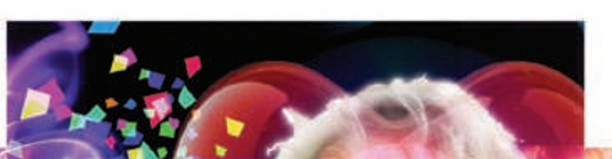

Auntie Merkel never brings a present, she brings something better. She's staring at the happy couple and she's sifting through their futures, unravelling the ball of tangled string to find the thread of their happy marriage.

Chaotic inflation means that the multiverse is always stretching, like a loaf of bread, forever baking in the oven of eternity. Auntie Merkel likes weddings; she likes this family; she likes this bubble universe that stopped expanding a while ago, and sits static in the bread. When this bubble formed in a spasm of spontane-

ous symmetry it enclosed linear time. You can keep the other $10^{10^{10^{7}}}$ bubbles with their diverse physical constraints. Auntie Merkel likes linearity; she likes ceremony; she likes repetition.

The couple make their vows.

A successful marriage is difficult, but in this bubbleverse there are plenty of worlds to choose from, there's room for happiness. Auntie Merkel searches for the doppelgängers of the happy couple; through the parallels and possibilities; through the Hubble volumes; discarding the myriad worlds of sadness, disappointment, divorce; always following one thread: there are three things that last forever ... the greatest of them all is love.

When the couple finish their vows and kiss, Auntie Merkel gives the couple their gift. Moira was right: Auntie Merkel is a romantic. And, although she never brings a present, she always gives the couple their future.

The wedding is over and the congregation waits outside the church while the couple sign the register.

Edith rummages in her handbag for a box of confetti.

"Where's Auntie Merkel?" asks Moira.

"She must have slipped away."

"Why Edith, you're crying."

Edith wipes away the tear. "I had such a happy marriage, Moira."

Moira grips her sister's hand so tightly that her knuckles show white through the skin. "I know, my love. We both did. We were both blessed."

Deborah Walker lives in London with her partner, Chris, and her two lovely, yet distracting, young children. 